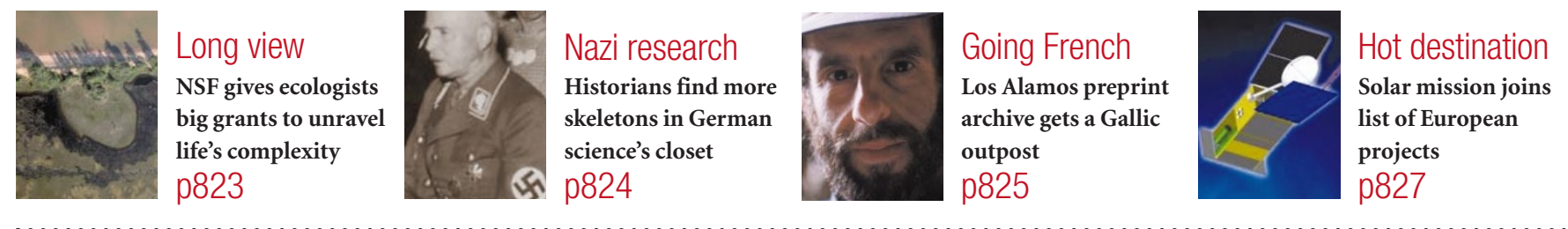

\title{
Tissue donors use their influence in deal over gene patent terms
}

Paul Smaglik, Washington

A genetic disorder is at the heart of what is believed to be a first for the intellectual property world. A joint patent application for a disease-causing gene is expected to be filed shortly by the researchers who isolated the gene and the patient advocacy group that helped them make the discovery.

The group, PXE International, provided scientists at the University of Hawaii with blood and tissue samples from patients with pseudoxanthoma elasticum, a genetic disorder that causes connective tissue in the skin, eyes and arteries to calcify.

The novel alliance could become a model for handling intellectual property emerging from collaborations between patients' groups and researchers. Sharon Terry, president of PXE International, says that the group made the move because it wants to ensure that licences for any resulting genetic tests will be inexpensive and widely available.

The application comes at a time when both the US National Bioethics Advisory Commission and the Human Genome Organization are emphasizing that genetic researchers should share the benefits of their research with the subjects who make it possible (see Nature 403, 237 and 404, 912; 2000).

PXE International filed a provisional patent in February, shortly after the gene was isolated (see Nature Genetics 25, 223-227; 2000). It is now working out terms with the university before submitting the final application. The organization advocates free licensing but says that if the university insists on a fee, it will push to keep it low and will make sure any profits are split between the collaborators.

Terry, who calls negotiations between PXE International and the university "amicable", is optimistic that the two will soon come to terms. "Both of us are concerned that tests and treatments be accessible and low cost," Terry says. "We have the same goals in mind."

To protect patients' interests, PXE International set up its own blood and tissue bank. Researchers wanting to use the samples must agree to the group's terms, which include joint possession of any intellectual property that might result.

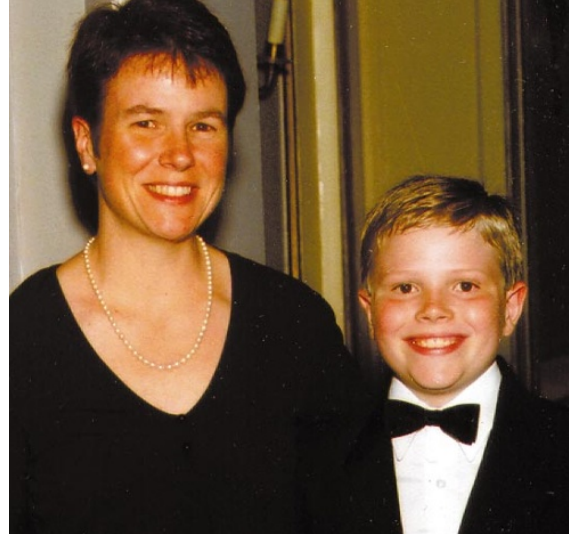

Right moves: Ian Terry's genetic illness led his mother Sharon to set up PXE International.

Previous collaborations in which the researchers have retained the complete rights to their findings have sometimes raised concerns. One notable example is the isolation of the gene for Canavan's disease, a neurological disorder characterized by the degeneration of the myelin sheath, the protective insulation for the brain's nerve cells.

After supplying samples to the Miami Children's Hospital, many parents were upset when the hospital sought exclusive licensing on the tests, Judith Tsipis, a biology professor at Brandeis University, who lost a child to the disease, told the American Society of Human Genetics meeting in Philadelphia this month.

Such restrictions are contrary to good science and medical practice, Tsipis said. "Anything short of open licensing limits the abilities of laboratories to do testing." She says that she is pleased that PXE International took control of its members' samples, and hopes more groups do the same.

Elizabeth Thomson, co-director of the Ethical, Legal and Social Implications programme at the National Human Genome Research Institute (NHGRI), says that this is a possibility. Thomson helped PXE International to set up its sample repository and data registry, mostly by giving the group advice on informed consent and drawing up guidelines that would limit how researchers could use the material. The NHGRI did nothing to encourage the group to seek intellectual property, she says.

Other genetic disease groups might follow PXE's example - an umbrella organization for such disease groups, Genetic Alliance, has been watching the group's moves closely. http://www.pxe.org

| http://www.geneticalliance.org

\section{Spain's science figures under fire}

\section{Xavier Bosch, Barcelona}

The science commission of Spain's opposition Socialist Party announced last week that it will file an amendment to the government's proposed science budget for 2001 on the grounds that military spending "has been camouflaged as spending on research and development".

The commission claims that basic research "has been forgotten" in the budget, in which "one in two pesetas are devoted to defence". Its statement follows a report in last week's Nature that the government was misleading scientists by including military funds in the budget for research and development (see Nature 407, 664; 2000).
Alfredo Pérez-Rubalcaba, minister of education and science in a former socialist government, says that the Nature story matches his own data. He claims that only Pta47 billion (US\$250 million) of the total budget increase of Pta572 billion will find its way to basic research. The results would be "a theoretical $6.6 \%$ increase but this is only one point above the growth of the Spanish economy".

In contrast, the budget for military projects will increase by $12 \%$. PérezRubalcaba emphasized that, although his party is not opposed to investment in defence, "it must not be registered as $\mathrm{R} \& \mathrm{D}$ spending". 